\title{
FOOD SAFETY VERSUS AN INDIVIDUAL IN THE THEORY OF ECONOMICS
}

\author{
One knows little of little life \\ unlesshe has a theoretical system \\ by which to interpret it. \\ (J.K. Galbraith, The New Industrial State, 1967)
}

\begin{abstract}
The paper attempts to define theoretical grounds for the phenomenon of food safety. Usually, food safety refers to two key areas: the presence of foreign substances in food and food falsification. The former describes food safety in terms of health, the latter in terms of economic aspects. The focal point of the analysis is the "individual", whose status is very different in respective theories of economics. The discussions compared the approach to the role and character of the individual in all major schools of economic thought ranging from classical liberalism, Keynesian school, Schumpeterian school to neo-institutional and behavioural schools. The author concludes that what best explains the behaviour of individuals in its market activity as regards food safety is the neoclassical approach. Finally, the paper formulates the prerequisites to provide consumers with the desired food safety status.
\end{abstract}

Keywords: food safety, individual in the theory of economics, food quality, schools of economic thought, technostructure.

JEL codes: A11, L66, Q18. 


\section{Food safety today}

According to Galbraith, there is little in theory that cannot be tested in life. Meanwhile, South Korean economist Chang claims that every solution in the economic policy, as well as activities of any company are supported by some economic theory either inducing or justifying these activities (Chang, 2015). The objective of the article is an attempt to embed issues and processes constituting food safety in an economic theory. This attempt focuses mainly on explaining theoretical grounds of phenomena that lead to deterioration of food safety or even to its elimination, i.e. loss of safe food status by food products (usually a part of them) and becoming unsafe food. The article puts forward an argument that risks to food safety result not really from the market competition mechanism - although, in part also - but from the behaviour of an individual ${ }^{1}$ focused on achieving maximum benefits from their activity (maximum usefulness).

The concept of food safety - being a part of the broader concept of food security - generally refers to two major areas, i.e.: (1) presence of foreign substances in food, which usually are not present in it (such as food contaminants, residues of veterinary medicines and pesticides), and (2) food falsification (also lowering food quality). The former describes food safety in terms of health, the latter in terms of economic aspects (Kowalczyk, 2016). Possible types of risks to food safety are illustrated in Figure 1. They may be classified using two basic criteria: purposefulness of activities and area of risks.

The risks resulting from purposeful (deliberate) and conscious activity on the part of an individual (entity, company) are the most important and most dangerous. Depending on the area of safety they relate to, they may include: (1) food falsification in relation to food components and its labelling, and (2) bioterrorism involving illegal (criminal) actions consisting in adding foreign substances to food, mostly biological contamination of food.

\footnotetext{
${ }^{1}$ An "individual" is most generally defined as a specific individual acting and shaped by economic processes. This definition is wider than homo oeconomicus, as it concerns the concept of an individual in all theories of economics. Human activity is also manifested in fields other than the economy, such as social relations, and then we may talk about a human as a social individual. Thus, it would be more appropriate to use the definition of the individual as an economic individual in this paper, but since the latter term may have different meanings in economics, the paper uses the term "individual", without specifying the individual's area of activity which, in this case, is, naturally, the economy.
} 


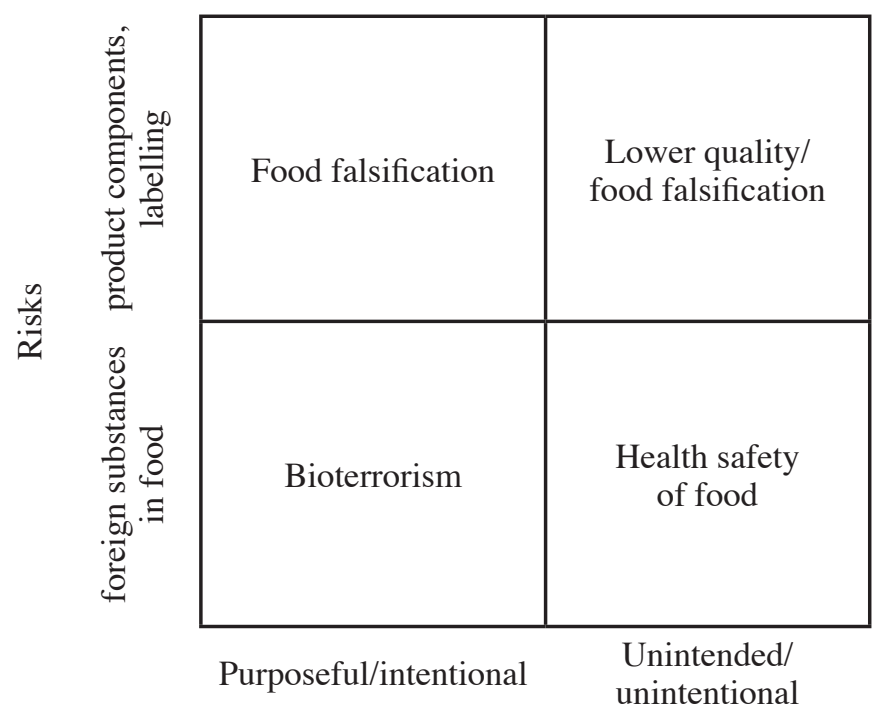

Activity

Fig. 1. Matrix of food safety risks.

Source: own study.

In the case of unintentional (accidental) activities, consequences for food safety can be divided into conscious and unconscious (resulting from the individual's ignorance). An example of the former (activity which is conscious, but with no intent to harm other individuals - consumers, competitors) ${ }^{2}$ is (1) conscious use of components containing residues of pesticides and/or veterinary medicines in quantities exceeding the maximum permissible levels in food production, while an example of the latter may be (2) the use of components with the same status, but resulting from ignorance of the individual (producer), which may be due to negligence with regard to technological regimes (such as failure to perform laboratory tests of raw materials used for food production to cut the manufacturing costs). The above activities result, firstly, in reduced food quality or even its falsification and, secondly, in lower health safety of food or even the loss of the safe food status and becoming unsafe food. The difference between the two above-mentioned situations lies only in whether or not this activity was conscious.

The individual's activities in the area of food falsification (to a lesser extent, also in terms of reducing its quality) are motivated by the wish to obtain "additional" profit, exceeding the one that can be obtained legally (without resorting

\footnotetext{
${ }^{2}$ Although we could expect negative consequences of such acts, even with minimal interest on the part of the individual.
} 
to food falsification). Activities consisting in food contamination are, first of all, performed in order to eliminate competition (it concerns the cases of contaminating the food produced by competitors which often happens in some regions of the world such as Asian countries) and also to achieve other goals, usually political (as a consequence of bioterrorism acts). In general, an individual is motivated to pursue activities which are illegal or even criminal in terms of food safety in order to achieve their own interests, primarily related to profit and maximising the usefulness of the individual. Therefore, these actions are the outcome of rationality of the individual's actions, although somewhat illinterpreted. Fortunately, bioterrorism is relatively rare compared to instances of food falsification or its accidental contamination.

The above-analysed issues are very important in the modern, globalised economy due to systematic increase - starting from the turn of the third and fourth quarter of the $20^{\text {th }}$ century - in intensity of food safety level reduction, both in health and in economic terms. This phenomenon has the form of a great surge in food falsification and contamination whose range is inferior to the first surge from the mid-19 ${ }^{\text {th }}$ century. (Kowalczyk, 2016). The phenomena such as food falsification and/or contamination (chemical, biological, mechanical/physical and organic) reduce or even eliminate food safety. This gives rise to a question about the grounds (and causes) of this phenomenon, its practical consequences and, above all, its theoretical justification, since the lack of food safety is a risk to consumer health and life in health terms and a manipulation of market processes by food falsifiers and fraudsters.

Explanation for these phenomena is sought for in various processes and aspects, but the most reasonable seems to be to link them with the behaviour of an individual that, apart from the market and the state, is an essential player in every economic and social reality. However, neither the state nor the market with a depersonalised mechanism of competition and elimination, which is so typical of this category, assume any negative motivation or wish to dominate. As opposed to an individual who, by preferring self-interest to any other values, usually resorts to such activities.

In the Ricardian concept of the capitalist economy, an individual means a landowner, a capitalist and a worker (Ricardo, 1821, p. 5). In the considerations on food safety a worker - as an individual - does not matter much. Although we can state that there is an increasing number of events on the market that are initiated by individuals who are not economic operators. Such events involve e.g. acts of bioterrorism, food contamination as part of unfair competition, but these issues are not covered by this paper. The most important issue discussed in the article is the behaviour on the food market, first of all, the behaviour of an individual-economic operator and secondly the behaviour of a group of individuals forming the company management. 


\section{Individual in the theory of economics}

Regardless of professed beliefs or created theoretical concepts, economics as a science has always been and is involved in the three main categories, namely: market, state and individual. Here, we are interested mainly in the role and position of an individual in the theory of economics - the extent of an individual's decisive role in social and economic processes, whether he/she is a creator, a source or a beneficiary of the created wealth and, finally, whether this individual is egoistic, greedy and quarrelsome, or altruistic and willing to prefer general interest over self-interest. This last dimension of the individual is particularly interesting, since it determines the individual's position in the hierarchy of the society, economy, wealth and, finally, civilisation. Either it is the role of the demiurge of everything and prosperity, or, just the opposite, the source of destruction, mainly in the non-Schumpeterian "creative" sense of this word.

How, therefore, does the theory of economics, in its various forms and schools, define the position of an individual and the individual's behaviour towards other market participants? The assessment of this behaviour is of key importance to determine the potential impact of an individual on market developments, including food safety. The analysis of possible behaviour of an individual should, first of all, take into account the approach of the classical school of economic thought ${ }^{3}$.

\section{Classical liberalism}

A discussion on the role of an individual in the economic development was consciously or not - initiated by the creator of modern economics, Adam Smith $(1723-1790)^{4}$. He wondered what really drives human actions and came to the conclusion that this is primarily an expectation or even desire to achieve own benefits. Thus, when we address a Smithian butcher, brewer or baker, we do not expect of them humanity or benevolence, and therefore, "we never talk to them of our own necessities but of their advantages" (Smith, 1776, p. 14). We address their egoism. An individual's actions are not driven by altruism, the will to help others or act in public interest, but everything an individual does (the butcher referred to by Smith several times) he does it, bearing in mind "only his own security". And the fact that it brings specific benefits to the society as a whole is the "merit" of the famous invisible hand by which this butcher is "led to promote an end which was no part of his intention" (Smith, 1776, p. 246).

This is how for many years an individual has become selfish and rational in the theory of economics. Although, as Wilkin says, it would be more accurate

\footnotetext{
${ }^{3}$ Classification of schools of economic thought adopted according to: Chang (2015).

${ }^{4}$ Ethical, psychological and social issues of human nature were discussed by Smith earlier in another paper, which was said to be even more important for him than The Wealth of Nations (The Theory of Moral Sentiments, 1759).
} 
to call an individual a dramatic creature. This is a consequence of constant pressure, to which a contemporary human being is subject in connection with a constant dilemma: how to reconcile numerous necessities and social roles with the need to ensure economic growth (Wilkin, 2016).

The model of homo oeconomicus - yet not directly named like that - has been theoretically formulated by English philosopher and economist Mill (1806-1873) . Mill wrote: "any human being should be a selfish egotist, devoid of every feeling or care". However, for Mill it was not a necessary condition for an individual's happiness. Just the opposite. He believed that both the law and social (interpersonal) relations should be shaped in a way ensuring that an individual's interest was as close to the public interest as possible.

Ricardo (1772-1823), regarded by many people to be a continuator of Smith's thought, tried to explain selfish behaviour of an individual in a relatively simple way. He writes: "There can be no rise in the value of labour without a fall of profits (of the entrepreneur)" (Ricardo, 1821). Thus, we should not be surprised by the attitude of an individual who wants to take and keep for himself as much as possible.

The classical school unanimously formulates the position of an individual in the market and justifies its behaviour. The economic rationality is superior, human and social considerations are fully subordinate. There is no room for altruism, or for accepting actions that do not result from economic account. An individual is, first of all, selfish and focused on achieving his own, utilitarian goals.

\section{Marxian school}

The Marxian school presents strong views on the role and status of the individual in the theory of economics. Marx identifies two groups of individuals in the market, calling them classes: capitalist class (including landowners) and working class. The relations between these two groups of individuals are characterised by a constant struggle, the subject of which is a wage obtained by workers for their work. As the capitalist can live longer without the worker than the worker can without the capitalist, it is the capitalist who determines the wage level (Marx, 1960).

According to Marx, an individual has a clearly defined status. The capitalist is a rational individual from the point of view of his goals and is extremely selfish. In case of the worker, it is difficult to determine the rationality of his behaviour, as he mainly struggles for survival, of both himself and his family, which, however, to some extent evidences the rationality of his action (Marx, 1960). The antagonism of these two groups, that is, capitalists and workers, is taken for granted also by other representatives of the Marxian school, such as Kautsky (1946).

\footnotetext{
${ }^{5}$ The term homo oeconomicus was introduced by Italian economist Vilredo Pareto (1848-1923), representative of the Lausanne school (neoclassical trend) in his paper: V. Pareto (1906). Manuale di Economic Politica con una introduzione alla scienza sociale. Società Editrice Libraria, Milan, Italy, p. 14.
} 
The Marxian school determines the differently understood rationality of individuals belonging to various classes: the rationality of the capitalist is determined by the strive for maximising profits, of the worker - by obtaining sufficient funds to provide for himself and his family. Egoism is a typical feature of the capitalist class while the working class is characterised by consent for the common fight for interests of other people, but only those belonging to the working class.

\section{Austrian (praxeological) school}

The Austrian school presents an approach to the role of the market and the individual which is similar to that of the (Neo)classical school. One of the main representatives of this school, von Mises (1881-1973) writes: "Human action is purposeful behaviour" (von Mises, 1998, p. 11), but the ultimate goal of human action is always the satisfaction of the acting man's desire" (von Mises, 1998 , p. 14). According to von Mises, at the origin of every human action is the desire to remove uneasiness that always accompanies the individual. This is a consequence of the simple and brutal fact that "...man is a beast of prey whose inborn natural instincts impel him to fight, to kill, and to destroy" (von Mises, 1998, p. 169).

Despite this definite assessment of the individual's attitude, von Mises ultimately rejects the concept of homo oeconomicus as something fictional. According to him, the Austrian school "nor deals with a fictitious homo oeconomicus. It treats the inexorable categories of everybody's action. (...) It is time to discard entirely any reference to the abortive attempt to justify the shortcomings of older economists through the appeal to the homo oeconomicus phantom" (von Mises, 1998, p. 64). The individual usually acts rationally but its behaviour is also determined by cultural and institutional conditions, thus is partially unpredictable.

The second pillar of the Austrian school, von Hayek (1899-1992), also stresses the importance of the individual in the economy. Everybody, in fact, in their action is driven, more or less reasonably, by expectations as to the results of their action. On the other hand, success or failure will depend on whether what the individual does fits in with the other parts of that larger processes which are undertaken or contemplated at the same time by other people (von Hayek, 2009). In turn in one of the most famous papers by von Hayek, The Road to Serfdom (1944), the author writes that it is of minor importance whether the ends for which any person cares comprehend only his own individual needs, or whether they include the needs of his closer or even those of his more distant fellows that is, whether he is egoistic or altruistic, as the individual human even when he takes a warm interest in the welfare of every human being he knows, the ends about which he can be concerned will always be only an infinitesimal fraction of the needs of all men (von Hayek, 2009). 
This means that an individual is generally selfish in his actions, although in conditions of the full political and economic freedom he also acts for the interests of other people (society). An individual is also usually rational in his behaviour, however, this does not apply to collectivist systems.

\section{Schumpeterian school}

According to Schumpeter (1883-1950), an individual is the most important because he is responsible for implementing innovation and makes decisions on the future of a company (Noga, 2009). The involvement of other stakeholders, such as the government, research institutions, non-governmental organisations, significantly narrows down the scope of action and possibilities of decisionmaking by an individual, thus restricting his behaviour, which, in turn, leads to making irrational decisions.

Schumpeter argued that economic changes "compel individuals and groups to behave in certain ways whatever they may wish to do" (Schumpeter, 2003, pp. 129-130). However, experience shows that it is extremely difficult to identify a person for whom altruism or a sense of duty exists in total independence of their own egoism (self-interest) or of simple vanity or desires of the individual.

Therefore, for Schumpeter, an individual, although trying to act rationally, in view of the numerous obstacles inherent in the environment and resulting from actions of other stakeholders (state, competition, social groups), does not always make rational decisions. Certainly, this is an individual closer to egoism rather than to altruism and public interest.

\section{Keynesian school}

In his papers, Keynes (1883-1946) referred to the status of an individual. In his opinion, an individual's market behaviour is determined to a greater extent by spontaneous behaviour rather than by rational, economic or moral predictions and expectations. Therefore, it is more a result of animal spirit of the individual and, consequently, spontaneous drive for action, rather than of cold calculation (Keynes, 1936).

An individual does not always need to act rationally. This also means that certainly the individual's action is not always selfish or egoistic. Spontaneity and natural tendency to act based on an internal instinct rules out this possibility, although Keynes does not say it straightforward. In general, for the Keynesians an individual is not the most important. The supporters of this school of thought are willing to attribute the principal role of economic success to the state's involvement rather than to spontaneity and resourcefulness of an individual.

\section{Neoclassical school}

In general, the Neoclassical school is a continuator of the Classical school. Both schools share the same approach to an individual's behaviour on the mar- 
ket. According to the representatives of the Classical and Neoclassical school, an individual is driven only by self-interest and benefits from implemented market transactions.

Marshall (1842-1924), one of the creators of the Neoclassical school, tries to justify, in a sense, an individual's behaviour in the capitalist system, writing that: "the best energies of the ablest inventors and organisers (...) are stimulated by a noble emulation more than by any love of wealth for its own sake" (Marshall, 1920, p. 1). An individual's behaviour and action is driven, however, mainly by self-interest, here - financial interest, which is a source of wealth.

Lucas (born 1937), representative of the new classical economics assumes that: "all agents [individuals - S.K.'s note] behave optimally in light of their objectives and expectations, and expectations are formed optimally" (Lucas, 1972 , p. 108). However, the rational individual's behaviour in the market requires providing this individual, at any time, with the applicable information necessary to verify the rationality of the action taken, therefore, the economic models being structured must take into account the individuals' strive for staying rational in its action.

The role of an individual on the market was presented very clearly by two Nobel Prize winners - Akerlof and Shiller ${ }^{6}$ - in their work under the meaningful title Animal spirits (2009). Despite their neoclassical provenience, they represent the sceptical trend against the ultraliberal Chicago school. As claimed by Akerlof and Shiller, in modern times, the concept of justice from the economic point of view has been pushed to the margins of thinking, while the market is more and more dominated by acting in "bad faith", corruption and diminishing fear of punishment which should be attributed to animal spirits (Akerlof and Shiller, 2010).

The assessment of an individual's behaviour within the framework of the Neoclassical school is a consequence of the Classical school's position. Therefore, an individual's actions are driven by the spirit of race, competition and a desire to defeat rivals. The scale of the directions of thinking as part of the Neoclassical school also translates into the more differentiated approach to the above assessment. The model of homo oeconomicus, as the dominant one, has been supplemented with new elements, such as: (1) strive for being rational rather than being rational, (2) treating an individual as irrational in certain situations, (3) individual's actions driven by desires, tendencies or animal spirit on the market.

To put it simply, it may be assumed that an individual according to the Neoclassical school strives for rationality in the process of irrational behaviour. An individual is driven by egoism, wish to defeat rivals, but also by own desires and tendencies.

\footnotetext{
${ }^{6}$ Akerlof was awarded the Nobel Prize in 2001, Shiller in 2013.
} 


\section{(Neo)institutional school}

This school is characterised by two periods of evolution. The first, launched by the creator of the institutional school - Veblen (1857-1929), and the second, representing new institutional economics, whose main representatives are: North (1920-2015), Coase (1910-2013) and Williamson (born 1932).

According to Veblen, the struggle for wealth at the early stages of the economic development has always been a struggle for survival. At the higher stages of development, the struggle continues but its background is different. The struggle for wealth in the industrial era is competition for the higher quality of life, by increasing consumption of goods (Veblen, 1918/1922). This direction is driven by competition among individuals. Thus, Veblen challenges the classic rationality of the individual seeking to satisfy its own goal. The individual's action is driven both by reason and by a whole set of other motivations, such as strive for wealth, desire to impress others, to achieve a specific social position and, finally, the need to provide for own and family's subsistence.

In turn, Coase, a representative of new institutional economics (NEI), realised that an individual and a company in the modern economy are not autonomous in their decisions. An individual's (entrepreneur's) behaviour on the market is determined by transaction costs (Coase, 1992). The status of an individual in NEI is, however, much more complex than in Classical economics, since the individual must take into account not only own benefits, but also the behaviour of government administration (regulations, taxes, subsidies), market complexity and, finally, customs and beliefs of other individuals. Greater benefits can therefore be achieved through negotiations with other entities (companies) and with the government, rather than through egoistic behaviour, typical of homo oeconomicus.

This complexity of an individual's status on the market is also highlighted by Williamson, who writes that market benefits are a consequence of conflicting interests of individuals (companies). Therefore, it is much more beneficial to behave rationally, rather than, at all costs, to assert individual benefits with the use of false or misleading statements and market behaviour, leading to disputes and claims among companies (Williamson, 1979).

The individual's status in NEI, in comparison to other schools, such as the (Neo)classical school, is extremely complex. In general, NEI challenges the individual's rationality in its strive for achieving its own goals. The institution is more important in the economy rather than the individual. As a result, the individual may benefit more from negotiations with other individuals (companies) and with the government rather than from the egoistic behaviour, typical of homo oeconomicus. Therefore, the individual's action is driven both by reason and by a set of other motivations, such as strive for wealth, desire to impress others, achievement of a specific social position and, finally, the need to provide for own and family's subsistence. 


\section{Behavioural school}

In the most emphatic way, the (Neo)classical model of homo oeconomicus is challenged by the behavioural school. According to it, man is neither rational nor egoistic in his behaviour. Man has attempted to be rational, however, as this not always works, man is characterised by bounded rationality. Human action is guided by - in addition to the desire to be rational - also by typical human traits, such as emotions, loyalty, envy or justice.

Simon (1916-2001), one of the pioneers of behavioural economics and the critic of full rationality in the individual's behaviour, has created a model of bounded rationality. He understood it as the rational choice taking into account the cognitive limitations of a decision maker (individual). The bounds arise both from its knowledge (human reason), and the ability to process market information. Consequently, people are not able to assess whether or not an event or behaviour will help them increase their benefits (general interest, wealth) (Simon, 1982). Simon also puts into question the (Neo)classical egoism of the individual and considers two types of individuals: type $\mathrm{A}$ is altruistic, type $\mathrm{S}-$ selfish/egoistic. Although according to the Neo-Darwinism theory, the basis of natural selection is the "selfish gene", according to Simon the majority of population models "leaves some space for altruistic individuals" (Simon, 1982, pp. 207 and 208). What is more, these individuals can achieve greater benefits in the wake of their flexible behaviour than individuals driven by hard egoism only. In fact, bounded rationality often better fits submissive altruism rather than extreme egoism.

Therefore, the behavioural school strongly rejects the (Neo)classical model of homo oeconomicus and challenges the basic principles of this model, i.e. rationality of the individual's behaviour and its egoism. This is replaced by the category of the individual with bounded rationality, whose actions (apart from reason) are also driven by emotions, loyalty, envy and justice. In addition, the attitude of individuals, apart from typical egoism, may also be characterised by altruism and flexibility of behaviour, adapted to a specific situation.

\section{An individual's status in various schools of economic thought vs food safety}

The objective of the above comparative analysis of an individual's status and nature in various schools of economic thought ${ }^{7}$ was an attempt to identify the direction of (economic) thinking, where both positive and negative impact on food safety may be placed in the easiest and most confident manner. The individual and its motivations for the market activity are here important as the nega-

\footnotetext{
${ }^{7}$ Therefore, the above overview of schools of economic thought does not include the schools which attribute the fundamental importance not to the individual but to the phenomena inherent in the environment (business environment), as, for example, development economics, focused primarily on the process of economic development in backward countries and regions, or analysis of the nature and causes of mass poverty.
} 
tive impact on food safety results directly from the individual's market activity, including achieving its objectives and moving between egoism and altruism, justice and business ethics and violation of the law.

Therefore, the key question of the considerations made here is: if the individual is selfish, egoistic and makes decisions only based on verifiable economic criteria, i.e. is rational in its action, or if it is altruistic, making decisions based on emotions, experience, ethical criteria or intuition, i.e. is not always rational. The answer to this question allows to conclude on the possible consequences of action of individuals in the economy, including also the failure to observe or even violation of the basic rules of cooperation and principles of business ethics. Synthetic summary of the conclusions from the analysis is included in Table 1.

Generally, it should be concluded that the status (nature) of the individual evolves over time, both in terms of rationality and egoism. Starting from the position of the classical school, we can identify two major trends of this evolution as regards thinking about the individual's rationality. The first one is the trend which argues that the individual's rationality varies in representatives of various social classes (Marxian school) or the individual only tries to be rational (Schumpeterian school), can also act spontaneously, which, in principle, excludes its full rationality (Keynesian school), finally, is rational, but has complex expectations, which, in turn, does not exclude the possibility that this individual tries, in any conditions, to achieve its own goals and objectives (Neoclassical school). The second one assumes the partial or complete irrationality of the individual, and thus the rejection of the model of homo oeconomicus (Austrian school, (Neo)institutional school, behavioural school).

In the case of the second dimension of the individual, i.e. its egoism/altruism in social and market action, we may conclude with some surprise, that the views of the individual schools of economic thought are, to a large extent, convergent. In fact, quite commonly dominant is the belief of egoistic, selfish action of the individual striving only for its own objectives and unable to subordinate its own objectives to the public objective (synthesis of homo oeconomicus and animal spirit by the Neoclassical school). Some schools only stress that despite the fact that the individual generally strives for achieving only its own objectives, in certain conditions and cases it may act altruistically (Austrian school, behavioural school) or flexibly, according to the circumstances, but only in anticipation of a more favourable achievement of own objectives, rather than acting egoistically in a consistent manner (Neoinstitutional school). 
Table 1

Status of the individual according to various schools of economic thought

\begin{tabular}{|c|c|c|}
\hline School & Individual's rationality & Individual's egoism \\
\hline Classical & $\begin{array}{l}\text { Individual is rational in achieving } \\
\text { own goals; a prototype of homo } \\
\text { oeconomicus }\end{array}$ & $\begin{array}{l}\text { Egoistic, selfish course of action, } \\
\text { no room for altruism and participation } \\
\text { in implementing common interests }\end{array}$ \\
\hline Marxian & $\begin{array}{l}\text { Rationality of action is typical } \\
\text { of all individuals, however, } \\
\text { it is different for representatives } \\
\text { of various classes }\end{array}$ & $\begin{array}{l}\text { Egoism is a typical feature of } \\
\text { capitalists, for workers such feature } \\
\text { is the fight for common interests } \\
\text { of the class (workers) }\end{array}$ \\
\hline $\begin{array}{l}\text { Austrian } \\
\text { (praxeological) }\end{array}$ & $\begin{array}{l}\text { The individual is rational in } \\
\text { its action, apart from collectivist } \\
\text { systems; the basis for rational action } \\
\text { of the individual is its political } \\
\text { freedom }\end{array}$ & $\begin{array}{l}\text { In general, the individual is } \\
\text { characterised by egoism, although } \\
\text { we cannot say that it is not interested } \\
\text { in the public interest; however, } \\
\text { it should implement its own values, } \\
\text { not the values of the other }\end{array}$ \\
\hline Schumperian & $\begin{array}{l}\text { The individual tries to be rational } \\
\text { in its action, however, as a result } \\
\text { of action of other stakeholders its } \\
\text { decisions are only partially rational. }\end{array}$ & $\begin{array}{l}\text { More typical of the individual is } \\
\text { the egoistic behaviour rather than } \\
\text { altruism and preferring the interests } \\
\text { of others to self-interest }\end{array}$ \\
\hline Keynesian & $\begin{array}{l}\text { The individual often acts } \\
\text { spontaneously, which means } \\
\text { that it is not always rational } \\
\text { in its action }\end{array}$ & $\begin{array}{l}\text { The individual's animal spirit and } \\
\text { internal instinct as a basis of action } \\
\text { are reasons for which the individual } \\
\text { may act egoistically but not in every } \\
\text { situation }\end{array}$ \\
\hline Neoclassical & $\begin{array}{l}\text { The complex nature of the } \\
\text { individual, resulting from the model } \\
\text { of homo oeconomicus; } \\
\text { the individual strives for rationality } \\
\text { and achievement of its own } \\
\text { objectives; complex market } \\
\text { expectations }\end{array}$ & $\begin{array}{l}\text { The individual is driven by egoism, } \\
\text { will to defeat rivals, but also by its } \\
\text { own desires and tendencies }\end{array}$ \\
\hline (Neo)institutional & $\begin{array}{l}\text { The complex status of the } \\
\text { individual; challenging the } \\
\text { individual's rationality; the } \\
\text { individual's action is guided both } \\
\text { by reason and a set of motivations } \\
\text { (strive for wealth, desire to achieve } \\
\text { the social position, etc.) }\end{array}$ & $\begin{array}{l}\text { Due to the greater importance of the } \\
\text { institution than of the individual in } \\
\text { the economy, benefits desired by the } \\
\text { individual can be brought more easily } \\
\text { by negotiations with other individuals } \\
\text { or with the government, rather than } \\
\text { by selfish action typical of homo } \\
\text { oeconomicus }\end{array}$ \\
\hline
\end{tabular}

The model typical of the individual is bounded rationality; its action

Behavioural is also guided by considerations such as emotions, loyalty, envy or justice
The attitude of individuals, apart from egoism, may also be characterised by altruism and the flexibility of action adapted to a particular situation

Source: own study. 
As recognised synthetically by Chang, the individual is selfish "most of the time", but it is also not unfamiliar with such behaviour and emotions as patriotism, altruism, sense of justice, commitment to ideology, strive for beauty or just curiosity.

The above findings showing the nature of the individual focused predominantly on its own objectives, egoistic and not much willing to see the interest of others or of the public, and in addition enslaved by the institutional environment, are not an optimistic prospect for explaining the possible attitude of the individual to food safety.

\section{Theoretical perspective of food safety}

If we assume that homo oeconomicus and, to a lesser extent, also socioeconomicus, as a theoretical model, really does not fit into the modern theories of economics, as it is unable to explain the major part of market behaviours typical of the individual, it has lost, first of all, its topicality regarding the rationality of the individual's action. The question arises: has the individual ever been characterised by such rationality? In fact, as Polanyi described this type in a sarcastic and emphatic manner, the "primeval man bent on barter and truck" defined by Smith is known not to have indulged in those laudable passions (Polanyi, 2010).

The second essential feature of homo oeconomicus, i.e. egoism and defence of self-interest is, on the other hand, very much accurate also in modern times. In some respects, it is even strengthened in relation to its original, i.e. the Smithian butcher. There are many examples of individuals' behaviour which is extremely egoistic and even brutal from the market point of view. Individuals, which today are hiding under the collective banner of technostructure, dominate in each organisation. In the state sphere - in a form of a public agency, in the private sphere - of a modern corporation. Today, an individual's objective is the organisation's (agency, corporation) objective, i.e. the situation of classical adaptation within the meaning of Galbraith, where an individual's objectives have become synonymous with the corporation's objectives. Today, this is the most effective way for an individual to achieve his own objectives.

In addition, to make the argument complete, it should be added that the behaviour of individuals supervising and managing the third group of stakeholders - apart from natural persons and the market, i.e. individuals forming government authorities, or government officials, does not differ from other two groups. As claimed by Chang, it would be naïve, if not delusive, to expect that the public interest will be more important for them than their self-interest (Chang, 2015).

The above findings lead to a conclusion that what best explains individuals' behaviour in their market activity in the area of food safety, is the approach belonging to the canon of the Neoclassical school. The approach stressing the egoism of the individual consisting in preferring self-interest and benefits to those of the public. An individual who, due to complexity of modern market 
processes, is unable to individually act reasonably in all conditions. Who always tries to be rational from the point of view of self-interest. From the point of view of own rationality, an individual perceives cooperation within a group of individuals (technostructure) to be more beneficial. This leads the individual to form systems, cooperation, collaboration with other individuals, or adaptation and adjustment of self-interest to the interest of technostructure and corporation. This also determines such actions as a negative impact on food safety through its falsification, and even contamination, in order to obtain additional benefits (income), even at the expense of all consumers.

From this it follows that, as clearly demonstrated by the overview of the schools of economic thought - we should not count on common altruism of individuals. This would be naïve and even absurd. What are thus possible and real solutions to protect consumers against reduction or even loss of food safety? The necessary measures must go in two directions: (1) strengthening the role of the state and its agencies, and (2) improvement in the effectiveness of the market mechanism in this area of food law. It is easy to note that in the latter area, the role of the state and its authorities is also important.

In general, the main phenomena requiring the state's intervention in economic affairs, including food safety - regardless of the views on this issue held by e.g. the Neoliberal school - include "more than a random tendency to produce and sell goods and services with technical defects or physically harmful" (Galbraith, 1999, p. 68). In the area of food, it means the tendency which has been described here many times, if not to contamination, then certainly to falsification of food and lowering its quality. The regulatory activity of the state in this area is essential, at least in order to shape, according to the consumer needs, the unplanned and often spontaneous response of individual producers or corporations. This response is not always consistent with the interest and wishes of consumers, but is in line with the objectives of individuals or these corporations. Even if we assume that the currently dominant model is the one with a significant social "stigma", i.e. the model of socioeconomicus.

The state cannot refrain from activity in this area, because it is the only structure able to face and oppose the actions contrary to the public interest. Therefore, the state cannot - although this behaviour is encountered also with respect to its authorities - act egoistically and selfishly, using as an excuse the lack of competence to act, due to the fact that today certain phenomena are taking place outside its borders ${ }^{8}$. In the age of globalisation, the majority of market phenomena are transnational. This fully applies also to the food market. Corporations functioning in the global dimension may be opposed only by an alliance of government authorities, and not by individual consumers. An example of such

\footnotetext{
${ }^{8}$ According to the argument provided by Galbraith "That's another country - they are not our problem". See: Galbraith, 1999, p. 107.
} 
action is the prevention of food falsification, trade in food which is defective or harmful to life and health of consumers. In such cases, effective may only be joint action of control authorities from many countries, and not consumers, their organisations or even the authorities of individual countries acting in isolation ${ }^{9}$.

In the area of the market, the most important activities include the formation of its processes in order to protect the weakest link of the food chain, i.e. the consumer. However, also here an active role of the state is necessary. Otherwise, an individual, regardless of the attributed additional characteristics and qualities placing the individual farther from or closer to the classical model of homo oeconomicus, or even socioeconomicus, will dominate the modern social and economic systems, and the particular interest of an individual (or a group, technostructure) will always overcome the public interest of consumers in general. Therefore, achieving and maintaining the desired state of food safety requires shaping the relations between two major social categories i.e. the individual and the state in a manner which will provide the relevant scope of authority of the state and its bodies (including, in particular, official food control institutions) over the market, and consequently, and over the individual's activity. However, this is not about imposing administrative constraints on an individual's economic freedom, but - according to the terminology of new institutional economics - about developing formal institutions and their executive powers, i.e. legal regulations and corresponding enforcement instruments, i.e. sanctions (North, 1994), which will guarantee that relations between individuals on the market will not lead to risks to food safety, and thus to health and life of consumers.

\footnotetext{
${ }^{9}$ An example of such effectiveness of cooperation among national control authorities of individual countries is the "OPSON" operation implemented since 2011. More on this: Kowalczyk, 2016.
} 


\section{References}

Akerlof, G.A., Shiller, R.J. (2010). Zwierzęce instynkty. czy natura psychika napędza globalna gospodarke i jaki to ma wpływ na przemiany światowego kapitalizmu? Warsaw: Wydawnictwo Studio EMKA.

Chang, H.-J. (2015). Ekonomia. Instrukcja obstugi. Warsaw: Wydawnictwo Krytyki Politycznej.

Coase, R.H. (1992). The Institutional Structure of Production, University of Chicago law occasional Paper, no. 28. Retrieved from: http://chicagounbound.uchicago.edu/occasional_papers.

Galbraith, J.K. (1999). Godne społeczeństwo. Program troski o ludzkość. Warsaw: PTE, Dom Wydawniczy Bellona.

Galbraith, J.K. (1973). Społeczeństwo dobrobytu - państwo przemysłowe. Warsaw: PIW

Hayek, F.A. von (2015). Droga do zniewolenia. Cracow: Wydawnictwo ARCANA.

Hayek, F.A. von (2009). The Pure Theory of Capital. Alabama: The Ludwig von Mises Institute, Auburn.

Kautsky, K. (1946). The Intellectuals and the Workers. Fourth international, vol. 7, no. 4.

Keynes, J.M. (1936). The General theory of Employment, Interest and Money. Macmillan Cambridge University Press.

Kowalczyk, S. (2016). Bezpieczeństwo i jakość żywności. Warsaw: Wydawnictwo Naukowe PWN.

Lucas, R.E. (1972 ). Expectations and the Neutrality of Money. Journal of Economic Theory, vol. 4.

Marks, K. (1960a). Praca najemna i kapitał. In: K. Marks, F. Engels, Dzieła wybrane, vol. I, Warsaw: Książka i Wiedza.

Marks, K. (1960b). Rękopisy ekonomiczno-filozoficzne z 1844 r. In: K. Marks, F. Engels, Dzieła, vol. 1, Książka i Wiedza. Retrieved from: https://www.marxists.org/polski/marks -engels/1844/rekopisy/index.htm.

Marshall, A. (1920). Principles of Economics. $8^{\text {th }}$ edition, London: Macmillan and Co., Ltd., book I, chapter II, $\S 1$. Retrieved from: http://www.econlib.org.

Mill, J.S. (1985). The Collected Works of John Stuart Mill. Vol. X - Essays on Ethics, Religion, and Society (1833), J.M. Robson (ed.), Introduction by F.E.L. Priestley, Toronto: University of Toronto Press, London: Routledge and Kegan Paul.

Mises, L. von (1998). Human action: a treatise on Economics. Alabama: Ludwig von Mises Institute Auburn.

Noga, A. (2009). Teorie przedsiębiorstw. Warsaw: Polskie Wydawnictwo Ekonomiczne.

North, D.C., (1994). Economic performance through time. American Economic Review, vol.84(3) p. 360. Retrieved from: https://tu-dresden.de/gsw/phil/iso/mak/ressourcen/ dateien/lehre/download/rntexte/north.pdf.de.

Pareto, V. (1906). Manuale di Economic Politica con una introduzione alla scienza sociale. Milano: Società Editrice Libraria.

Pigou, A.C. (1920). The Economics of Welfare. London: Macmillan and Co., Limited St. Martin's Street.

Polanyi, K. (2010). Wielka transformacja, polityczne i ekonomiczne źródła naszych czasów. Warsaw: Wydawnictwo Naukowe PWN. 
Ricardo, D. (1821). On the Principles of Political Economy and Taxation. $3^{\text {rd }}$ edition, London: John Murray.

Sargent, T.J., Wallace, N. (1974). Rational Expectations and the Theory of Economic Policy, University of Minnesota. Working Paper, August, no. 29, p. 15. Retrieved from:https:// www.minneapolisfed.org/research/wp/wp29.pdf.

Schumpeter, J.A. (2003). Capitalism, Socialism and Democracy. London and New York: Taylor \& Francis e-Library.

Simon, H.A. (1982). Models of Bounded Rationality: Empirically grounded economic reason. Vol. 3. London: MIT Press, Cambridge Massachusetts.

Smith, A. (1776). An inquiry into the nature and causes of the wealth of nations. London, s. 14. Retrieved from: http://www.ifaarchive.com/pdf/smith.

Veblen, T. (1918/1922). The Theory of the Leisure Class: an Economic Study of Institutions. New York: B.W. HUEBSCH.

Wilkin, J. (2016). Instytucjonalne i kulturowe podstawy gospodarowania. Humanistyczna perspektywa ekonomii. Warsaw: Wydawnictwo Naukowe Scholar.

Williamson, O.E. (1979). Transaction-Cost Economics: The Governance of Contractual Relations. Journal of Law and Economics, vol. 22, no. 2, p. 240. Retrieved from: www. jstor.org/stable/725118.

Wojcieska, L. (2014). Współczesna koncepcja homo socio-oeconomicus. Studia Ekonomiczne Uniwersytet Ekonomiczny w Katowicach, no. 180, part 1. Dokonania współczesnej myśli ekonomicznej: racjonalność - efektywność - etyka., cz. 1, Problemy teoretyczne. 
STANISEAW KOWALCZYK

Instytut Ekonomiki Rolnictwa i Gospodarki Żywnościowej

- Państwowy Instytut Badawczy

Warszawa

\title{
BEZPIECZEŃSTWO ŻYWNOŚCI A JEDNOSTKA W TEORII EKONOMII
}

\begin{abstract}
Abstrakt
W artykule podjęto próbę określenia podstawy teoretycznej zjawiska, jakim jest bezpieczeństwo żywności. Z reguty bezpieczeństwo żywności odnosi się do dwóch zasadniczych obszarów, tj. obecności substancji obcych w żywności, zwykle w niej nie wystepujacych oraz fatszowania żywności. Pierwszy obszar zagadnień określa bezpieczeństwo zdrowotne żywności, drugi jej bezpieczeństwo ekonomiczne. W centrum przeprowadzonej analizy stoi ,jednostka”, której status jest określany bardzo różnie w poszczególnych teoriach ekonomicznych. W rozważaniach porównano podejście do roli i charakteru jednostki we wszystkich podstawowych szkołach ekonomicznych, odnoszacych się do tych spraw, poczawszy od szkoły klasycznej liberalnej przez. szkołe keynesowska, schumpeterowska do (neo)instytucjonalnej oraz szkoły behawioralnej. W konkluzji autor dochodzi do wniosku, że tym, co najpełniej wyjaśnia zachowanie jednostki w jej aktywności rynkowej w zakresie bezpieczeństwa żywności, jest podejście zawarte w kanonie szkoły neoklasycznej. W zakończeniu sformułowane zostały warunki niezbędne do zapewnienia konsumentom pożadanego stanu bezpieczeństwa żywności.
\end{abstract}

Słowa kluczowe: bezpieczeństwo żywności, jednostka w teorii ekonomii, jakość żywności, szkoły ekonomiczne, technostruktura.

Accepted for print: 15.10.2017.

Unless stated otherwise all the materials on the website are available under the Creative Commons Attribution 3.0 Poland license. Some rights reserved to the Institute of Agricultural and Food Economics - National Research Institute.

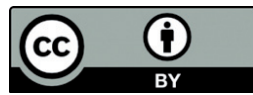

